\title{
PERFORMANCE IMPACT OF THE APPLICATION OF CASTOR OIL BIODIESEL IN DIESEL ENGINES
}

\section{LEONARDO DE A. MONTEIRO ${ }^{1}$, GUILHERME PIANOVSKI JÚNIOR ${ }^{2}$, JOSÉ ANTONIO VELÁSQUEZ ${ }^{3}$, DANILO S. ROCHA ${ }^{4}$, ANDRÉ V. BUENO ${ }^{5}$}

\begin{abstract}
The use of renewable fuels, such as the biodiesel, can ease the demand of fossil fuel for the power generation and transportation fields in rural area. In this work, the performance impact of the application of castor oil biodiesel is evaluated with an automotive and a stationary diesel engine. The application of B20 and B10 biodiesel blends and pre-heated net biodiesel is considered. The viability of the employment of B10 and B20 blends to mobility and power generation was observed from dynamometric bench tests, where this blends performed similar to fossil diesel. With the pre-heated net biodiesel, however, a brake torque loss and a specific consumption increase were observed with relation to diesel fuel.
\end{abstract}

KEYWORDS: Biodiesel, Castor Oil, Diesel Engine, Dynamometric Bench Tests.

\section{IMPACTO DA UTILIZAÇÃO DO BIODIESEL DO ÓLEO DE MAMONA NO DESEMPENHO DE MOTORES DIESEL}

RESUMO: A utilização de fontes renováveis de energia, como o biodiesel, pode coibir o uso dos combustíveis fósseis empregados na geração de potência e no transporte rural. Neste trabalho, avaliou-se o impacto operacional da aplicação do biodiesel de mamona em um motor diesel automotivo e em um motor diesel estacionário de médio porte, estudando-se as alterações provenientes da utilização deste biocombustível puro preaquecido e, como misturas, B10 e B20. Observou-se em bancada a viabilidade de aplicação das misturas B10 e B20, tanto em mobilidade quanto em geração de trabalho elétrico, pois as mesmas obtiveram desempenho similar ou superior ao do diesel mineral. Contudo, resultados inferiores de torque de frenagem e um aumento no consumo específico foram obtidos com o biodiesel de mamona preaquecido B100 com relação ao óleo diesel.

PALAVRAS-CHAVE: Biodiesel, Óleo de Mamona, Motor Diesel, Ensaio Dinamométrico.

\section{INTRODUCTION}

Government programs have encouraged the use of different types of biomass, according to the availability of each region. With respect to biodiesel, goals are set for their gradual addition of fuel oil, following a plan to increase the percentage of concentration to expressive values. Thus, changes in the operating conditions of the internal combustion engine from the addition of conventional biodiesel to diesel fuel should be evaluated in detail.

At the beginning of the implementation of national biodiesel program, there was a great expectation of obtaining this fuel from castor oil, a compatible culture production systems adopted in family farms and fully adapted to the semi-arid. From the point of view of the analysis of internal combustion engines, there is still another concern as to the study of biodiesel from castor beans: due to their unique physical and chemical characteristics, such as viscosity nearly six times that of mineral diesel fuel, it is expected that its addition to mineral diesel can causee radical modifications

\footnotetext{
${ }^{1}$ Prof. Dr. Universidade Federal do Ceará - UFC, Máquinas e Mecanização Agrícola - Dep. Eng. Agrícola - Pici.

${ }^{2}$ Universidade Federal do Ceará - UFC, Mestre em Engenharia Mecânica - Dep. Eng. Mecânica - Pici.

${ }^{3}$ Prof. Dr. Universidade Tecnológica Federal do Paraná - UTFPR, Máquinas Térmicas - Dep. Acadêmico de Mecânica - Rebouças.

${ }^{4}$ Universidade Federal do Ceará - UFC, Mestre em Engenharia Mecânica - Dep. Eng. Mecânica - Pici.

${ }^{5}$ Prof. Dr. Universidade Federal do Ceará - UFC, Máquinas Térmicas - Dep. Eng. Mecânica - Pici.

Recebido pelo Conselho Editorial em: 17-5-2011

Aprovado pelo Conselho Editorial em: 30-6-2013
} 
and therefore sharper than other types of biodiesel on engine performance. Moreover, transport and electricity generation in decentralized producing regions of castor oil could also be made possible employing biodiesel in automotive and stationary engines, eliminating the need for transportation and acquisition of diesel on a large scale. This type of policy has proved to be attractive both from the economic point of view, as under the social point of view (PIANOVSKI et al., 2002). Despite this, there is still a clear gap in the literature regarding the availability of data on the effects of the use of biodiesel from castor. The unique features of this biodiesel, such as high viscosity, may have contributed to the lack of studies framework. In fact, biodiesel from castor has a kinematic viscosity of $14.51 \mathrm{cSt}$ - a value considerably higher than the maximum of $5.5 \mathrm{cSt}$ specified by ANP for fuel used in diesel engines. In this way, in order to be able to operate a diesel engine with pure biodiesel from castor oil plant, for example, one should employ a pre-heater fuel in order to reduce its viscosity to values predicted by the standard. Another limiting factor for the application of castor oil in biodiesel production is the industrial demand for this oil of high commercial value, used in the manufacture of plastics, paints, lubricants and cosmetics.

In tests with a model Valtra BM 100 4x2 TDA pulling by five rods, subs oiler TABILE et al. (2009) obtained a behavior of specific fuel consumption increased with addition of castor biodiesel to conventional diesel. In this work, the authors have kept the engine running at 2000 rpm rotation. However, data from tests on stationary diesel engines or diesel fast (high speed) operating with pure castor biodiesel (B100) is not available in the literature.

In fact, most of the papers dealing with the operational performance of biodiesel employed methyl esters of soybean oil, rapeseed or sunflower. The results obtained with the addition these types of biodiesel in diesel highlight the importance of the modifications introduced in the fuel properties: composition change with the introduction of oxygen, reduced energy content and increased viscosity. These changes, in turn, causes a depletion in the combustion process which can be associated with an increase efficiency of the thermal engine (BUENO et al. 2009, 2011). Thus, data have been reported where the thermal efficiency of the engine is increased with the addition of biodiesel (BUENO et al., 2009; AGARWAL et al., 2001, ALI et al., 1995) or remained virtually unchanged RAKOPOULOS et al. (2007).

The specific consumption of the engine is given by the ratio between the calorific value of the fuel and thermal efficiency of the engine, settling for his behavior a compromise between increasing thermal efficiency and reducing the calorific value of the fuel with the addition of biodiesel. The best compromise between these factors has been achieved with the adoption of B10 blends (BUENO et al, 2009; 2011) and B20 (CASTELLANELLI et al., 2008; AGARWAL et al., 2001), with which it had mean reductions of approximately $2 \%$ in specific fuel consumption with respect to diesel fuel.

\section{MATERIAL AND METHODS}

\section{Fuels}

The base fuel used in this study was metropolitan diesel low sulfur (0.05\%). We used the methyl route for obtaining biodiesel from castor oil in the Laboratory of Internal Combustion Engines, Federal University of Ceará, Brazil. Table 1 presents some of the characteristics of the relevant thermo chemical fuels analyzed obtained by ROCHA (2011).

Due to the presence of oxygen in its composition, and the lower the carbon / hydrogen, the addition of biodiesel causes a reduction in the energy content of the fuel and the air-fuel mass ratio required for stoichiometric burning $a_{\text {st }}$ (see Table 1). For the B20 blend, there are highs of $27.3 \%$ in viscosity and $1.3 \%$ in density, and reductions of $3.6 \%$ in energy content and $5.7 \%$ in the fraction of air required for stoichiometric burning.

The rheological characterization of the castor bean biodiesel was carried out using a HAAKE Model RS 150 Rheometer, obtaining absolute viscosity data as a function of fuel temperature. 
Through the experimental results shown in Figure 1, it was determined that biodiesel from castor beans should be above $50^{\circ} \mathrm{C}$ to meet the requirement of maximum absolute viscosity of $0.005 \mathrm{~Pa}$.s standard established by ANP and at $64^{\circ} \mathrm{C}$ the absolute viscosity of biodiesel from castor oil equals the mineral diesel (which is $0.0035 \mathrm{~Pa}$-s at $40^{\circ} \mathrm{C}$ ). The following variables are shown in this figure: absolute viscosity curves (green), torque (blue) and angular frequency (red) obtained for biodiesel as a function of temperature. In order to maintain similar viscosity characteristics between biodiesel preheated and conventional diesel fuel, we used a temperature of the fuel $64{ }^{\circ} \mathrm{C}$ in dynamometer tests conducted with B100 and $40^{\circ} \mathrm{C}$ in the tests conducted with B20 and conventional diesel.

TABLE 1. Properties of the diesel fuel, biodiesel and B20 fuel blend.

\begin{tabular}{ccccccc}
\hline & $\begin{array}{c}\text { \%Biodiesel } \\
\text { (Volume) }\end{array}$ & $\begin{array}{c}\text { Empirical } \\
\text { Formula }\end{array}$ & $\begin{array}{c}\text { Ast } \\
{\left[m_{a r} / m_{f}\right]_{s t}}\end{array}$ & $\begin{array}{c}\text { Density } \\
{\left[\mathrm{kg} / \mathrm{m}^{3}\right]}\end{array}$ & $\begin{array}{c}\text { Viscosity } \\
{\left[\mathrm{m}^{2} / \mathrm{s} \mathrm{a} 40^{\circ} \mathrm{C}\right]}\end{array}$ & $\begin{array}{c}\text { Exergy } \\
{[\mathrm{MJ} / \mathrm{kg}]}\end{array}$ \\
\hline Diesel & $0 \%$ & $\mathrm{C}_{13} \mathrm{H}_{23} \mathrm{O}_{0.00}$ & 14.38 & 850.0 & $2.6010^{-2}$ & 44.98 \\
B20 & $20 \%$ & $\mathrm{C}_{13.66} \mathrm{H}_{24.43} \mathrm{O}_{0.33}$ & 13.77 & 861.3 & $3.3110^{-2}$ & 43.35 \\
Biodiesel & $100 \%$ & $\mathrm{C}_{19} \mathrm{H}_{36} \mathrm{O}_{3}$ & 11.64 & 924.5 & $14.5110^{-2}$ & 38.48 \\
\hline
\end{tabular}

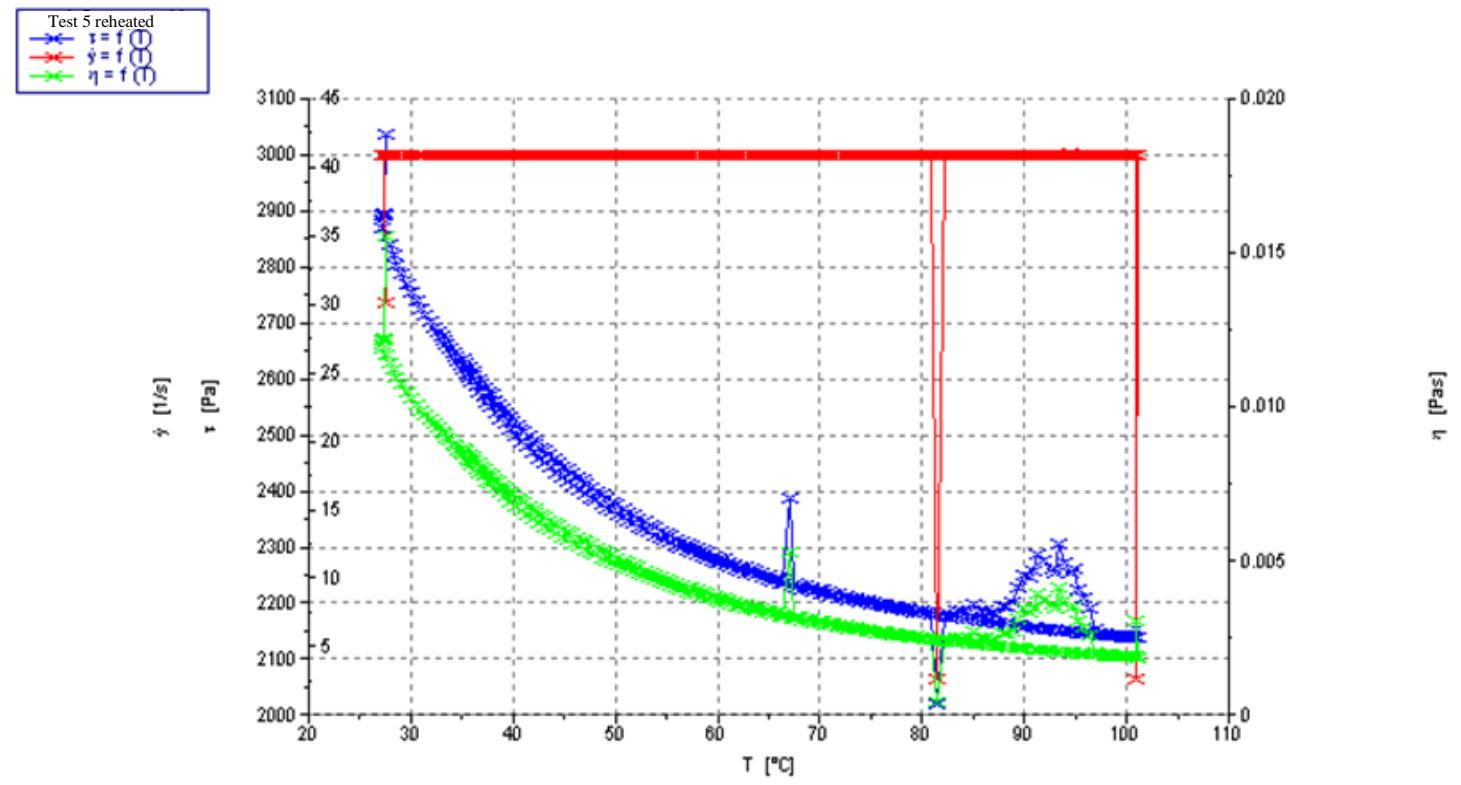

FIGURE 1. Rheological behavior of the castor oil biodiesel.

\section{Engines and countertops Dynamomentic}

The experiments were conducted in two different experimental setups, the first being located in the laboratory engine test at the Pontifical Catholic University of Paraná. This counter offer is a stray currents dynamometer and a system for automated testing of AVL. This used a counter balance for the gravimetric determination of the consumption of fuel and heat exchanger type shelland-tube to control the cooling fluid temperature and intake air. The automotive engine used in countertop PUC-PR was a MWM SPRINT TURBO GMT 400, whose technical specifications are listed in Table 2. For the tests we used the following fuels: diesel, B10, B20 and B100 (preheated) Castor.

In the second experimental setup, located in the engine test laboratory of the Federal University of Ceará, Brazil we used an automatic dynamometer and similar systems to control temperature and fuel measurement. CFU of the counter used a stationary motor 229 MWM T6 whose specifications are also given in Table 2, used to diesel, B20 and B100 of castor. The 
measurement accuracy of the major operating variables in each laboratory is shown in Table 2. The measurements were taken at intervals of $200 \mathrm{rpm}$ and fractions of $12.5 \%$ of the maximum braking torque on each rotation, ensuring that the engine is operated steady. More information about the experimental procedures adopted can be found in (BUENO et al., 2009b).

TABLE 2. Specifications of the engines.

\begin{tabular}{lcc}
\hline Specifications & MWM SPRINT & MWM 229 T6 \\
\hline TURBO GMT 400 & \\
\hline Configuration & 4 stroke, direct & 4 stroke, direct \\
Displaced Volume [dm3] & injection and turbo & injection and turbo \\
Number of Cylinders & 4.2 & 5.88 \\
Valves per Cylinder (Intake / Exhaust) & 6 & 6 \\
Piston diameter [m] & $2 / 1$ & $1 / 1$ \\
Stroke [m] & 0.093 & 0.102 \\
Compression Ratio & 0.103 & 0.120 \\
Maximum Power [kW] & $17.8: 1$ & $15.9: 1$ \\
Maximum Admissible rotation [rpm] & 123.0 a 3400rpm & 92.0 a $1800 \mathrm{rpm}$ \\
\hline
\end{tabular}

TABLE 3.Uncertainties of the bench measurements.

\begin{tabular}{lcc}
\hline Parameters & PUC-PR & UFC \\
\cline { 2 - 3 } Braking power [kW] & \pm 0.32 & \pm 0.32 \\
Mass fuel consumption [g / h] & \pm 192 & \pm 100 \\
Volumetric consumption of air [m3 / h] & \pm 6 & - \\
Indicated pressure [bar] & \pm 0.67 & \pm 0.21 \\
\hline
\end{tabular}

\section{Calculated Variables}

The specific volumetric fuel consumption (svf) is given in terms of fuel density ( $f d$ ) and measurements of braking power $(\mathrm{Pb})$ and fuel mass flow $(\mathrm{mf})$ :

$$
s f c=\frac{\dot{m}_{f}}{\rho_{f} P_{b}}
$$

The brake thermal efficiency $(\eta)$ is a more fundamental parameter for comparisons between different fuels, taking into account differences in the energy contents (energies) of these fuels:

$$
\eta=\frac{P_{b}}{\dot{m}_{f} e x_{f}}
$$

exf being the specific flow energy of the fuel examined here (see Table 1). Combining Equations (1) and (2) it is possible to express the specific consumption of fuel in volumetric terms energy of the fuel and brake thermal efficiency:

$$
s f c=\frac{P_{b}}{\eta \rho_{f} e x_{f}}
$$

\section{Results and Discussion}

Figure 2 shows the maps of volumetric specific fuel consumption ( $\mathrm{ml} / \mathrm{kWh}$ ) and torque load obtained for diesel for biodiesel blends and preheated with MWM Sprint turbo GMT 400. 


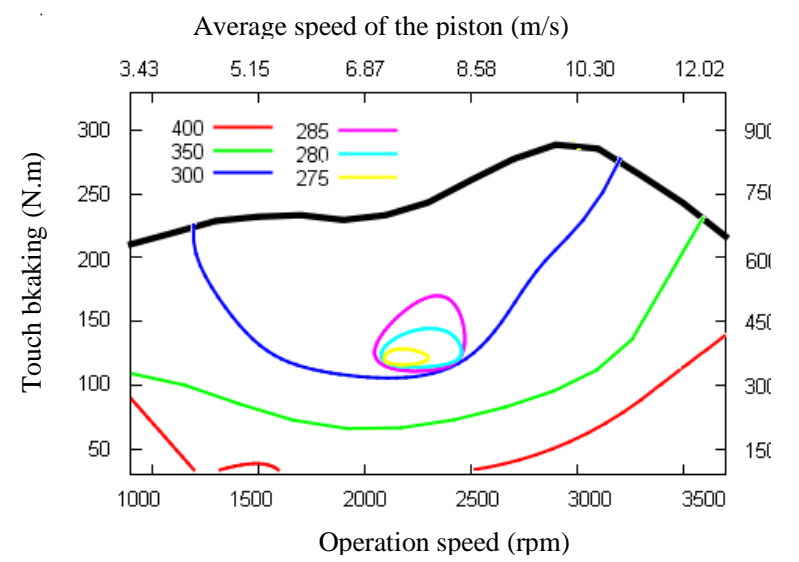

(Diesel)

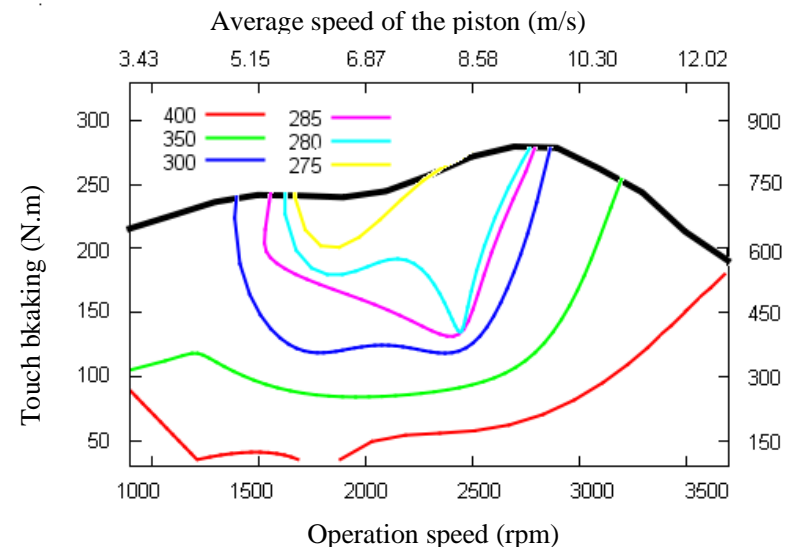

(B20)

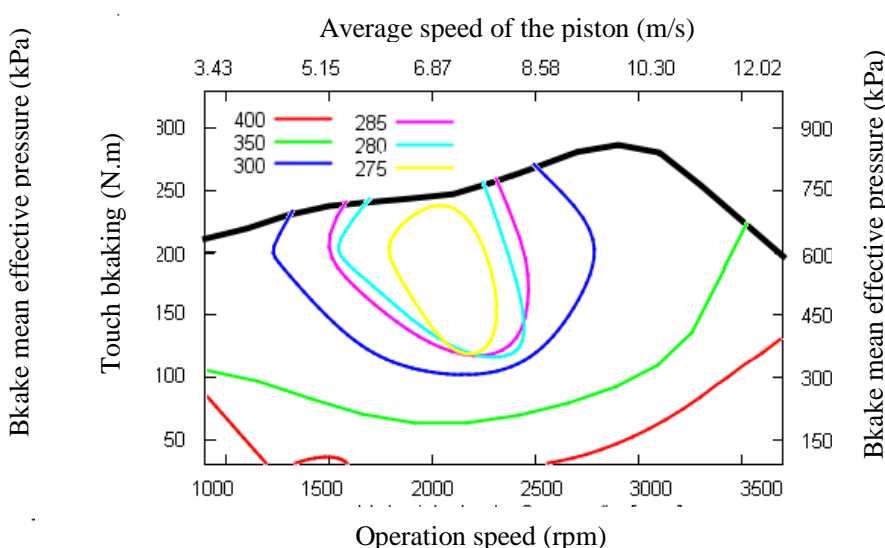

B(10)

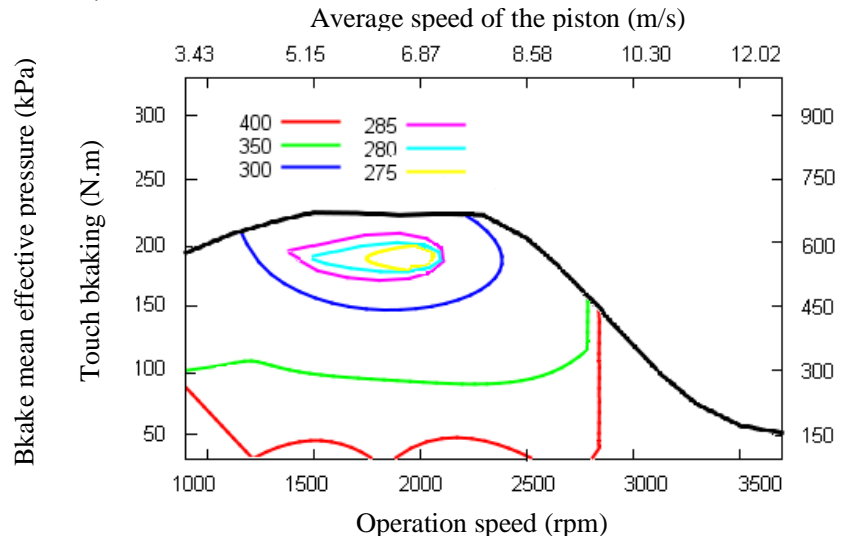

(Biodiesel Pre-heated)

FIGURE 2. Performance maps obtained with the engine MWM Sprint turbo GMT 400.

The use of biodiesel fuels with mixtures at concentrations below 20 volumes often associated with increases in engine thermal efficiency due to reduction in thermal losses and the energy of the exhaust gases. Data presented in Figure 3 for stationary diesel engine confirm this trend. Therefore, it is apparent that the behavior of the volumetric specific consumption of fuel is governed by a balance between the density and increases the thermal efficiency of the engine and reducing the energy content caused by the use of biodiesel, as observed by BUENO et al. (2009, 2011), (CASTELLANELLI et al. (2008) and AGARWAL et al. (2001).

This commitment was favorable to mixtures B10 and B20, including specific consumption values lower than those observed with diesel oil in much of the map of performance. However, the thermal efficiencies were not able to overcome the losses in the energy content of biodiesel fuel preheated where it is noted that the motor has a higher specific consumption using this fuel.
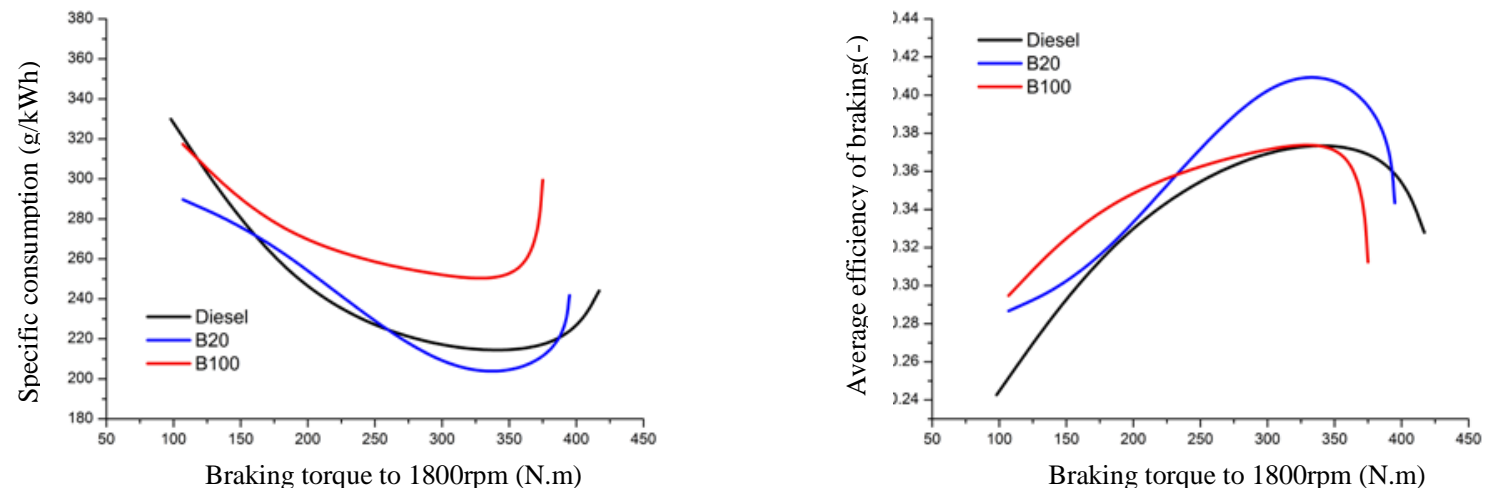

FIGURE 3. Operational results obtained with the engine MWM 229 T6. 
Also observed a large loss of torque in high rotation regimes with biodiesel from castor preheated. Although the device preheater have offset the effects of viscosity of B100, other factors such as density and high modulus of compressibility of this fuel eventually compromising the operation of the injection system rotations above $2000 \mathrm{rpm}$. As for the blends B10 and B20, the efficiency described earlier was able to satisfactorily sustain losses on the energy content of the fuel and the mass injected at full load, while maintaining the maximum torque of the engine almost unchanged in relation to diesel fuel.

Note the difficulty of using of castor biodiesel (B100) preheated in mobility applications. However, the results obtained show is acceptable for the application of this fuel in the MWM Sprint GMT 400 motor in stationary four-pole generators, which operate in a speed range close to 1800 rpm. Furthermore, mixtures provided a very satisfactory performance throughout the operating range of the engine.

Performance changes due to the application of biodiesel from castor oil were also much more expressive than those observed with soybean biodiesel (BUENO et al., 2009), even for the B20 blend. In addition to the factors associated with the injection system, this behavior can be attributed to the changes in the structure of the sharpest jet fuel caused by high viscosity and critical temperature of biodiesel of castor (BUENO et al. 2010).

Operating conditions corresponding to the production of electrical work with a four-pole generator were reproduced with the engine stationary MWM 229 T6. It has remained, therefore, the engine operating at a fixed speed of $1800 \mathrm{rpm}$ varying the braking torque at intervals of $10 \%$ of the maximum value. The main results with bench top motor 229 MWM T6 is shown in Figure 3.

The trends observed in the range of rotation of $1800 \mathrm{rpm}$ with the MWM Sprint GMT 400 motor were confirmed with the MWM 229 T6 motor. To the mixture B20, it was obtained an increase of the thermal efficiency, a small torque loss and maximum values very similar to diesel oil for the specific fuel consumption .For Biodiesel already preheated, it was found a reduction of 45 $\mathrm{Nm}$ maximum braking torque, and an average increase of $20 \mathrm{~g} / \mathrm{kWh}$ specific consumption with respect to diesel fuel, corresponding to a loss of about $10 \%$ to both parameters.

\section{CONCLUSIONS}

The operational impact of using biodiesel from castor oil was evaluated by dynamometer tests conducted with two turbocharged diesel engines. Yielded highly satisfactory results with blends B10 and B20 had, including specific consumption values lower than those observed with diesel oil in much of the map of performance. For such mixtures, it was confirmed the expectation that the increases in fuel density and thermal efficiency of the engine outweighed the effects of the reduction of the energy content promoted by biodiesel. These results therefore suggest the feasibility of its application both in mobility and in generation of electrical work.

In tests with B100 of castor preheated to appear torque loss and increase of specific fuel consumption by around 10\% at rotations below $2000 \mathrm{rpm}$, in addition to significant losses over this rotation. For this reason, it is recommended to use B100 biodiesel from castor preheated only in low-speed motors and generators equipment four or more poles, which operate at a range of speeds below $1800 \mathrm{rpm}$.

\section{ACKNOWLEDGMENTS}

The authors thank the National Council for Scientific and Technological Development (CNPq) for partial financial support to this study, given through project number 479450/2007-2 and 552809/2007-1. 


\section{REFERENCES}

AGARWAL, A.K.; DAS, L.M. Biodiesel development and characterization for use as a fuel in compression ignition engines, Transactions of the ASME, Piscataway, v. 123, p. 440-447, 2001.

ALI, Y.; HANNA, M.A.; LEVITICUS, L.I. Emissions and power characteristics of diesel engines on methyl soyate and diesel fuel blends, Bioresource Technology, Essex, v. 52, p. 185-195, 1995.

BUENO, A. V.; VELÁSQUEZ, J.; MILANEZ, L. F. Effect of soybean oil ethyl ester / diesel fuel blend on engine efficiency, International Journal of Vehicle Design, Jersey, v. 50, p. 229-257, 2009.

BUENO, A. V.; VELÁSQUEZ, J.; MILANEZ, L. F. A new engine indicating measurement procedure for combustion heat release analysis, Applied Thermal Engineering, Oxford, , v. 29, p. 1657-1675, 2009b.

BUENO, A. V.; ROCHA, D. S.; PIANOVSKI, G. Jr.; VELÁSQUEZ, J. Análise do desempenho de um motor diesel turboalimentado operando com mistura diesel-biodiesel. In: CONGRESSO NACIONAL DE ENGENHARIA MECÂNICA, 6., 2010, Campina Grande. Anais... Campina Grande: Associação Brasileira de Ciências Mecânicas, 2010.

BUENO, A. V.; VELÁSQUEZ, J.; MILANEZ, L. F. Heat release and engine performance effects of soybean oil ethyl ester blending into diesel fuel. Energy, Oxford, v. 36, n. 6, p. 3619-3944, 2011.

CASTELLANELLI, M.; SOUZA, S.N.M.; SILVA, S.L.; KAILER, E.K. Desempenho de motor ciclo diesel em bancada dinamométrica utilizando misturas diesel/biodiesel. Engenharia Agrícola, Jaboticabal, v.28, n.1, p.145-153, 2008.

PIANOVSKI JR, G.; VELÁSQUEZ, J.; TORRES, R. D. Perspectivas de ytilização no Brasil de biodiesel como substituto parcial do óleo diesel. In: CONGRESO CHILENO DE INGENIERIA MECANICA, 10., 2002, Cocim. Anales... Cocim, 2002.

RAKOPOULOS, C.D.; RAKOPOULOS, D.C.; HOUNTALAS, D.T.; GIAKOUMIS, E.G.; ANDRITSAKIS, E.C. Performance and emissions of bus engine using blends of diesel fuel with bio-diesel of sunflower or cottonseed oils derived from Greek feedstock. Fuel, London, v. 87, p. 147-157, 2007.

ROCHA D. S. Análise numérica do desempenho de um motor diesel turboalimentado operando com mistura óleo diesel-biodiesel de mamona. Dissertação (Mestrado em Engenharia Mecânica) Centro de Tecnologia, Universidade Federal do Ceará, Fortaleza, 2011.

TABILE, R. A.; LOPES, A.; DABDOUB, M. J.; DA CAMARA, F. T.; FURLANI, C. E. A. ; DA SILVA, R. P. Biodiesel de Mamona no Diesel Interior e Metropolitano em Trator Agrícola, Engenharia Agrícola, Jaboticabal, v.29, n.3, p.412-423, 2009. 